\section{Postharvest Infection of Highbush Blueberries following Contact with Infested Surfaces}

\author{
W.O. Cline \\ Department of Plant Pathology, Box 7616, North Carolina State University, \\ Raleigh, NC 27695
}

Additional index words. Vaccinium, quality, sanitation, decay, Colletotrichum, Alternaria

\begin{abstract}
The effects of inoculum, surface wetness, and stem scar on postharvest fungal infection of highbush blueberry (Vaccinium corymbosum L.) fruit were evaluated by exposing berries of the cultivars Bluechip (small, dry stem scar) and Blueray (large, wet stem scar) to infested and noninfested surfaces under wet or dry conditions. Rots caused by Colletotrichum gloeosporioides (Penz.) Penz. \& Sacc. in Penz. and Alternaria tenuissima (Kunze:Fr.) Wiltshire were evaluated. Field-harvested berries stored for 7 days at $21^{\circ} \mathrm{C}$ resulted in baseline infection levels of $1.5 \%$ ('Bluechip') and $18.7 \%$ ('Blueray') for $C$. gloeosporioides, and $\mathbf{1 0 . 1 \%}$ vs. $28.9 \%$, respectively, for A. tenuissima. Wet stem scars, infestation of handling surfaces, and addition of moisture were all responsible for increasing postharvest rots; however, most of the significant increases in rots occurred with a combination of two or more of these factors.
\end{abstract}

Postharvest decay of highbush blueberries is a serious problem in marketing channels on fruit from all major production areas in the United States (Cappellini et al., 1982). Mechanical harvesting and handling are welldocumented causes of increased bruising of highbush and rabbiteye (V. ashei Reade) blueberries (Austin and Williamson, 1977; Miller and Smittle, 1987). Decay of fruit increased in proportion to the amount of bruising in controlled laboratory tests (Ballinger et al., 1973) and in field tests (Mainland et al., 1975; Miller and Smittle, 1987)

Compared to hand-harvested fruit, fruit taken directly from the mechanical harvester and packed had more bruising and a higher incidence of decay (Mainland et al., 1975). In the same experiments, additional bruising and associated decay occurred when mechanically harvested fruit was sorted. During sorting, the fruit was conveyed to an air blast that removed leaves, trash, and small green berries. Following the air blast, fruit dropped to a conveyor for final inspection and removal of large green berries, ripe berries with obvious defects, and any remaining foreign matter. Fruit from the conveyor dropped into pulp cups and a cellophane cover was placed over the cup and held in place with a rubber band. Hand-harvested fruit was removed from the bush into 4.7-L pails and transferred directly to the pulp cups for cellophaning with no additional handling.

In the past 2 years, most blueberry producers in North Carolina and other states have

Received for publication 2 Nov. 1995. Accepted for publication 19 Apr. 1996. The cost of publishing this paper was defrayed in part by the payment of page charges. Under postal regulations, this paper therefore must be hereby marked advertisement solely to indicate this fact.

HortScience, Vol. 31(6), October 1996
Collection of fruit for testing. Tests were conducted in June 1994 using hand-harvested fruit from two midseason, large-fruited cultivars, 'Bluechip' (small, dry stem scar) and 'Blueray' (large, more tear-prone stem scar). Bushes were harvested every 7 days into clean containers under dry conditions, and were the first berries picked each day (8:00 to 10:00 AM). Pickers were instructed to skip any bush with one or more visibly infected, rotting berries in an attempt to avoid pretest contamination. Berries were selected to exclude green, overripe, soft, or insect-damaged fruit. Harvested fruit were transported to the laboratory and tests were conducted immediately.

Collection of inoculum. Two major postharvest rot organisms (Colletotrichum gloeosporioides and Alternaria tenuissima) (Ceponis and Cappellini, 1976; Farr et al., 1989) were selected for testing. Infected berries were collected from an area of the farm separate from test plots, and collection was based on the presence of visible spore masses on the surface of the fruit. The two fungi are easily separated visually since the former produces orange spore masses, while the latter is greenish-black. Identification was further confirmed by microscopic examination and by culture on acidified potato dextrose agar. Infected fruit of each type were collected and handled separately.

Inoculation method. Healthy test berries were exposed to inoculum of either $C$. gloeosporioides or A. tenuissima. A $50 \times 42 \times$ $4-\mathrm{cm}$ shallow, flat aluminum pan was used to simulate surfaces in the commercial hopper/ filler. The pan was infested by placing five infected, sporulating berries on the surface and slowly (two per second) hand-oscillating the pan $\approx 5$ to $10 \mathrm{~cm}$ in a horizontal plane for 5 $\mathrm{s}$, thus rolling the infected berries over the surface of the pan. Infected berries were then dumped out and not reused. One pint of healthy berries was then poured onto the infested surface and also oscillated for $5 \mathrm{~s}$. After exposure to the infested surface, berries were poured into new pint clamshell-type containers (Ultra Pac, Minneapolis), labeled, and set aside for later randomization and storage for 7 days at $21^{\circ} \mathrm{C}$. For wet treatments, the test surface was sprayed with $\approx 2.0$ to $2.5 \mathrm{~mL}$ of distilled water immediately before infected berries were rolled. The test surface was disinfested by wiping with $70 \%$ ethyl alcohol and drying between treatments. All treatments were replicated six times. The test was conducted twice and both runs combined for statistical analysis. Analysis of variance (ANOVA) procedures for balanced datasets (PROC ANOVA) were performed using statistical analysis software identified as SAS version 6.04 (SAS Institute, Cary, N.C.) and least significant difference (LSD) values were generated by this procedure for separation of means.

Inoculum levels. The amount of inoculum used in these experiments was estimated by measuring $C$. gloeosporioides conidial concentrations using two methods: 1) washing individual berries for spore counts and 2) 
rinse-collecting spores from the surface of the pan following infestation as described above. In method 1, individual sporulating berries collected from the field were immersed in 10 $\mathrm{mL}$ distilled water and brushed with camel's hair brushes to detach and suspend conidia in the distilled water. Spore counts were then made with the aid of a hemocytometer. One hundred sporulating berries were washed and conidia counted. This test also was conducted using berries infected by A. tenuissima. In method 2, the surface of the infested pan was flooded with $20 \mathrm{~mL}$ distilled water, brushed to dislodge spores, and poured off for spore counts as in method 1. The pan was infested and washed for spores a total of 50 times.

Infection sites. During the course of the experiment, it appeared that sites of infection on the berry surface were different for the two pathogens being evaluated. After experiments on early-season highbush cultivars were completed, a late-season follow-up study was conducted on available rabbiteye blueberry fruit ('Premier') to quantify these differences. Replicated four-bush plots were harvested and rolled as described previously. Berries were held for 10 days at $21^{\circ} \mathrm{C}$ and evaluated for site of infection (at stem scar vs. not at stem scar).

\section{Results and Discussion}

Most postharvest infections caused by $A$. tenuissima occurred at the stem scar on both cultivars tested. In evaluations of 'Premier' rabbiteye, $96 \%$ of all A. tenuissima infections occurred at the stem scar. Conversely, only $36 \%$ of infections by C. gloeosporioides were located at the stem scar, with the remaining $64 \%$ occurring via direct penetration of the berry surface. Infections by pathogens other than $C$. gloeosporioides and A. tenuissima were extremely rare and these infected berries were counted as healthy. Since fruit were collected from the field and were not surfacesterilized before testing, some naturally occurring infection was observed due to $C$. gloeosporiodes and A. tenuissima. These background levels of disease were significantly higher on 'Blueray', possibly due to its naturally wet stem scar providing adhesion and an infection court for spores.

Surface contamination. Washing individual sporulating berries infected by $C$. gloeosporioides recovered an average of $5.6 \times$ $10^{6}$ spores/berry. The multisegmented $A$. tenuissima spores averaged 5.8 segments/ spore, with an average of $8.1 \times 10^{4}$ spores collected from each naturally infected, sporulating berry. Colletotrichum gloeosporioides spores recovered by washing the surface of the infested pan averaged 158 spores $/ \mathrm{cm}^{2}$ in hemocytometer counts; however, distribution of spores over the surface of the pan was uneven. Observation of the contaminated surface during testing revealed visible masses of spores scattered over the surface. A noninfected berry coming into contact with one of these masses would be exposed to a high concentration of spores at the contact point.

Berry wetness during handling. In the presence of natural inoculum, infection of
'Bluechip' berries by both rot organisms and of 'Blueray' by $C$. gloeosporioides was increased with the addition of free water to the handling surface (Table 1). When inoculum was included, additive effects occurred in all combinations, but not always to a significant degree. Apparent synergistic effects between moisture level and inoculum level emerged only for 'Bluechip', and only when inoculated with $C$. gloeosporioides.

Wet vs. dry stem scar. As indicated previously, natural infection levels were significantly higher when fruit with wet stem scars were used. 'Bluechip', with its dry stem scar, showed no significant increase in disease over the controls until berries were handled wet (Table 1). The "worst-case" infection levels (wet, rolled, inoculated berries) indicated a higher level of susceptibility to Colletotrichum in 'Bluechip', with about two-thirds infected as opposed to about one-third for 'Blueray' (Table 1). However, 'Blueray' had consistently higher infection rates in all dry-rolled treatments, with 7 to 10 times the number of infected fruit. Dry-rolled 'Blueray' infection levels also were two to three times higher when Alternaria was evaluated, either with or without added inoculum. Interestingly, Alternaria infection still tended to occur at the stem scar on 'Bluechip' berries, indicating that even a small, dry picking scar provides a better infection court for Alternaria than the unbroken fruit surface. While this study provides evidence that stem scar wetness increases the likelihood of infection, it should be confirmed by hand-sorting berries of the same cultivar on the basis of stem scar size and wetness for use in comparative inoculations. This study has also shown that $C$. gloeosporiodes readily infects berries during postharvest handling and that postharvest infection by this pathogen is not limited to stem scar sites.

Postharvest rolling of 'Bluechip' or 'Blueray' on a clean, dry surface did not cause increased infection levels. Infection was significantly increased by the presence of moisture, either rolled onto the berry surface or in the form of wet stem scars on otherwise dry berries. Disease levels exceeded 50\% only in cases where added surface water and added inoculum were present. Fruit bruising in this study was purposely minimized by carefully rolling the fruit to evaluate only inoculum effects. Thus, any interaction of bruising with decay development was very nearly eliminated. Considerably more bruising can be expected with conventional sorting (Mainland et al., 1975) and with the filling/closing operation required for packing into clamshell containers. It appears from these studies that blueberry growers who wish to pack fruit on automated lines must 1) be certain the fruit is dry and 2) keep the handling surfaces sanitized by either periodic cleaning or by the exclusion of infected fruit before it can infest equipment. Mechanized cleaning and sanitation of conveyor belts and contact surfaces on a continuing or periodic basis would be desirable. Emphasis should be placed on the development and use of cultivars with dry stem scars, which will reduce the possibility of postharvest contamination even when berries are exposed to inoculum. Inoculum effects in handling imply the need for timely harvesting and close supervision of pickers to avoid introducing sporulating fruit into postharvest handling areas.

\section{Literature Cited}

Austin, M.E. and R.E. Williamson. 1977. Comparison of harvest methods of rabbiteye blueberries. J. Amer. Soc. Hort. Sci. 102:454-456.

Ballinger, W.E. and L.J. Kushman. 1971. Interrelationships of mechanical harvesting, bruising and decay of highbush blueberries, p. 38-47. In: Proc. of the Highbush Blueberry Mechanization Symp., 1-2 Nov. 1971, North Carolina State Univ., Raleigh.

Ballinger, W.E., L.J. Kushman, and D.D. Hammann. 1973. Factors affecting the firmness of highbush blueberries. J. Amer. Soc. Hort. Sci. 98:583587.

Ballinger, W.E., E.P. Maness, and W.F. McClure. 1978. Postharvest decay of blueberries as influenced by stem attachment and ripeness. Plant Dis. Rptr. 62:316-319.

Boyette, M.D., E.A. Estes, C.M. Mainland, and W.O. Cline. 1993. Postharvest cooling and handling of blueberries. North Carolina Coop. Ext. Serv. Publ. AG-413-7.

Cappellini, R.A. and M.J. Ceponis. 1977. Vulnerability of stem-end scars of blueberry fruits to postharvest decays. Phytopathology 67:118-119.

Table 1. Effects of postharvest wetting, handling, and contamination on infection levels in blueberry fruit caused by Colletotrichum gloeosporioides and Alternaria tenuissima.

\begin{tabular}{|c|c|c|c|c|c|}
\hline \multirow[b]{3}{*}{ Cultivar } & \multicolumn{5}{|c|}{ Treatment } \\
\hline & \multirow{2}{*}{$\begin{array}{l}\text { Surface } \\
\text { wetted }^{\mathrm{z}}\end{array}$} & \multirow{2}{*}{$\begin{array}{l}\text { Postharvest } \\
\text { handling }\end{array}$} & \multirow{2}{*}{$\begin{array}{l}\text { Handling surface } \\
\text { contamination }^{\mathrm{x}}\end{array}$} & \multicolumn{2}{|c|}{ Infected fruit after 7 days at $21^{\circ} \mathrm{C}(\%)$} \\
\hline & & & & C. gloeosporioides & A. tenuissima \\
\hline \multirow[t]{5}{*}{ Bluechip } & No & None & None & 1.5 & 10.1 \\
\hline & No & Rolled & None & 2.0 & 9.1 \\
\hline & No & Rolled & Inoculated & 3.6 & 10.3 \\
\hline & Yes & Rolled & None & 8.2 & 29.8 \\
\hline & Yes & Rolled & Inoculated & 63.5 & 25.0 \\
\hline \multirow[t]{5}{*}{ Blueray } & No & None & None & 18.7 & 28.9 \\
\hline & No & Rolled & None & 16.5 & 34.7 \\
\hline & No & Rolled & Inoculated & 26.1 & 37.3 \\
\hline & Yes & Rolled & None & 35.6 & 31.3 \\
\hline & Yes & Rolled & Inoculated & 31.4 & 71.7 \\
\hline $\operatorname{LSD}_{0.05}$ & & & & 8.1 & 7.4 \\
\hline
\end{tabular}

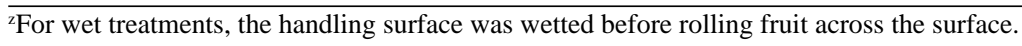

${ }^{y}$ For rolled treatments, berries were hand-oscillated slowly on a flat metal surface for $5 \mathrm{~s}$

'Inoculation of the handling surface for selected treatments was accomplished by rolling five infected, sporebearing fruit on the test surface for $5 \mathrm{~s}$. Each pathogen was evaluated separately. 
Cappellini, R.A., M.J. Ceponis, and G. Koslow. 1982. Nature and extent of losses in consumergrade samples of blueberries in greater New York. HortScience 17:55-56.

Ceponis, M.J. and R.A. Cappellini. 1976. Relative importance of alternaria rot in postharvest disease development in New Jersey blueberries. Plant Dis. Rptr. 60:569-571.

Ceponis, M.J. and R.A. Cappellini. 1978. Chemical control of postharvest rots in New Jersey blue- berries. Plant Dis. Rptr. 62:154-156.

Farr, D.F., G.F. Bills, G.P. Chamuris, and A.Y. Rossman. 1989. Fungi on plants and plant products in the United States. APS Press, St. Paul, Minn.

Mainland, C.M., L.J. Kushman, and W.E. Ballinger. 1975. The effect of mechanical harvesting on yield, quality of fruit and bush damage of highbush blueberries. J. Amer. Soc. Hort. Sci. 100:129-134.
Milholland, R.D. and R.K. Jones. 1972. Postharvest decay of highbush blueberry fruit in North Carolina. Plant Dis. 56:118-122.

Miller, W.R. and D.A. Smittle. 1987. Storage quality of hand and machine-harvested rabbiteye blueberries. J. Amer. Soc. Hort. Sci. 112:487490.

Ramsdell, D.C. 1994. Evaluation of foliar fungicides for control of postharvest fruit rots, 1993. F \& N Tests 49:57-58. 